\title{
HOW THE DRAGON GOT TWO TONGUES: ENGLISH VICTORIAN \\ VALUES AND THE EMERGENCE OF WELSH LITERATURE \\ WRITTEN IN THE ENGLISH LANGUAGE
}

\author{
COMO O DRAGÃO TEM DUAS LÍNGUAS: VALORES VITORIANOS INGLESES E \\ A EMERGÊNCIA DA LITERATURA GALESA ESCRITA EM LÍGUA INGLESA
}

\author{
Alan Peter Fear ${ }^{1}$
}

\begin{abstract}
The genesis of a Welsh literature written in the English language can be found in the turbulent middle ages, from the earliest Anglo-Saxon settlements on the island of Britain, to the Norman invasion and occupations of the late Medieval period. However, the emergence of this body of literature, sometimes referred to as Anglo-Welsh writing, can be attributed to many socio-political factors and events of the Victorian Age. At the apex of the British Empire the English educational system was implemented in Wales and an industrialization process meant that thousands of foreign immigrants were effectively diluting the native population driving the Welsh language and ancient culture to near extinction and promoting the use of the English language. As a consequence, Anglo-Welsh writing emerged fully towards the end of the $19^{\text {th }}$ century to the beginning of the $20^{\text {th }}$ century.
\end{abstract}

KEY WORDS: Anglo-Welsh Literature, Wales, Culture,

RESUMO: A gênese de uma literatura galesa escrita na língua inglesa pode ser encontrada na turbulenta idade média, desde os primeiros assentamentos anglo-saxões na ilha da GrãBretanha, até a invasão normanda e ocupações do final do periodo medieval. No entanto, o surgimento desse corpo de literatura, às vezes referido como escrita anglo-galesa, pode ser atribuído a muitos fatores e eventos sociopoliticos da era vitoriana. No ápice do Império Britânico, o sistema educacional inglês foi implementado no País de Gales e um processo de industrialização provocou o afluxo de milhares de imigrantes estrangeiros, efetivamente diluindo a população nativa, levando a língua e cultura galesas à quase extinção e promovendo o uso da língua inglesa. Como consequência, a escrita anglo-galesa emergiu plenamente no final do século XIX e no início do século XX.

PALAVRAS-CHAVE: Literatura anglo-galesa, País de Gales, Cultura

Welsh literature written in the English language is defined simply by writer Glyn Jones in his study of the genre, entitled The Dragon Has Two Tongues, as the literary production of

\footnotetext{
${ }^{1}$ Doutor em Literaturas de Língua Inglesa pela Universidade Federal do Rio Grande do Sul. Professor da Escola Superior de Propaganda e Marketing de Porto Alegre.
} 
"Welsh men and women who write in English about Wales" (JONES, 2001, p.37). The subject and content can vary considerably, though the matter is inevitably about Wales or the stories are set in Wales. Poet and Critic Jeremy Hooker observes that one reoccurring theme in AngloWelsh writing is one of identity; personal identity, national identity, cultural identity and human identity (HOOKER, 2001). The question of identity, in all its manifestations, is a complex issue of many factors, not the least of which is socio-historical, and the emergence of Anglo-Welsh literature and its subject matter is a consequence of many of these factors.

The $19^{\text {th }}$ century was the golden era of the British Empire with vast territories extending from Asia to North America, Oceania and large parts of Africa. The beginnings of this powerful empire can be traced back to the land-grabbing expansion projects of the Medieval AngloNorman Kings of $11^{\text {th }}-13^{\text {th }}$ century England. In the centuries following the withdrawal of the Romans from the islands of Britannia, and the incursions of the Germanic tribes, the land had been fought over until the emergence of three embryotic-nations, those of England, Scotland and Wales. The last of these, fragmented by petty-power struggles amongst its leaders and princes, Wales was easily conquered in its entirety by Edward I of England in 1282. After the physical work of war, the beurocratical work of governing and controlling of the restless population had to be promptly implemented. For these ends, a statute, sanctioned by Edward, imposed English law and administration over the defeated land. This was the beginning of the annexation of Wales to the Kingdom of England.

From that point on, over the centuries, Wales underwent a transformation of identity and culture leading to the Wales of today with a population very much aware of its heritage and maintaining a distinct cultural identity, formed through popular memory, myths and history, though communicated through the media of the English language rather than the ancient native Welsh language.

How did that transformation take place? What were the major factors which contributed to the near extinction of the Welsh language? A colonisation policy, effectively "diluting" the native population, was already in effect before Edward I's conquest. Normans had been settling in parts of South Wales and establishing towns from the time of when the first Norman king, William, defeated the last Saxon king, Harold, at the Battle of Hastings in the year 1066. From that year on, sanctioned by the King, the Norman Barons stormed over Britain pillaging and occupying territories, wherever and whenever it pleased them. On the Welsh border, where centuries before, the Saxon King Offa had established a physical demarcation line - a ditch and earth wall which nowadays we know as Offa's Dyke - the Norman Barons were allowed free reign by their king to invade into Welsh territory and grab as much land as possible at will, 
usually substantiating their hold with the Norman deadly weapon: the motte and bailey castle. The newly constructed castles were the bases for the establishment of towns, which in their turn would attract trade and induce a population growth.

With mass immigration and enforced English laws and administration, the traditional ancient Welsh way of life was being oppressed and transformed. This way of life was further eroded when, in 1535 and 1542, during the reign of Henry VIII, acts of parliament were passed which once again effectively annexed Wales to the Kingdom of England. The main purpose of these Laws in Wales Acts, as they became known, was to finally abolish any legal distinction between the Welsh and the English. As the surviving vestiges of Welsh law were already being eradicated, the acts merely endorsed what was an inevitable outcome. Welsh historian John Davies observes, "Thereafter, in the eyes of the law, the Welsh were the English." (DAVIES, 2007, p.233).

By the beginning of the $19^{\text {th }}$ century and the Victorian Age, Wales had gone through massive changes, the most impacting of all, however, was yet to happen. One of the greatest catalysts for social, economic and cultural change in Wales, quite possibly the greatest, was the series of technological advances that we now call the Industrial Revolution. In the $19^{\text {th }}$ century, coal and iron mining was exploited to its full extent in south-east Wales, transforming huge areas into extremely densely populated centres of misery and depression. Ancient native forest and green land were torn away to be replaced with steel and brick edifices; the noisy and polluting machinery of smelting furnaces and mine shafts filled the landscape. Thousands of people from England and further afield poured into the area in search of work. What remained of the Welsh language was squeezed to near extinction or pushed into the rural areas of the west and north. Davies notes that in the town of Trefethin, at the heart of the coal fields, it was estimated that in the 1840 s, as high as $44 \%$ of the inhabitants were of English origin (DAVIES, 2007). The dense population under harsh conditions resulted in social unrest, sparking riots and strikes amongst the mining and iron worker communities. The rural areas too were not without discontent. Between 1839 and 1844 a series of rebellions broke out as a violent protest against what the poor farming community saw as an unjust taxation system. From the biblical "Daughters of Rebecca" from which the rioters took their rallying call, these series of violent acts were termed the Rebecca Riots. Initially targeting the toll gates, which exacted heavy payment on any transport using the road systems around Wales, the rebels went on to attack stewards, tax collectors and landowners. The violence became too much for the government to ignore and troops were sent into the area to bring the situation under control. 
The aftermath of the uprisings and increasing political and social unrest forced the government in London to instigate an investigation into the causes, and the so-called Rebecca Commission was set up to identify trouble spots and come up with solutions. The findings of the commission were damning, pointing out the linguistic divisions between the upper and lower classes as the root of the problem, and that the Welsh language "hindered the Law and the Established Church from civilizing the Welsh" (DAVIES, 2007, p.387). It was recommended that a series of educational reforms be set in motion with the objective of 'civilizing the Welsh'.

Three years later, another similar commission was set up, proposed by Member of Parliament William Williamson, ironically himself a Welshman, who wished to investigate the state of education in Wales and the availability of education in the English language. Three English government officials travelled throughout Wales and gathered information through interviews with Anglican clergymen who had a very biased view against Welsh nonconformism - the prevailing form of religion in Wales at the time - and English school teachers who daily were faced with classrooms full of children who spoke no English. The result of the investigations was a report based only on the anti-Welsh sentiments of wealthy landowners, the Anglican church and monoglot English speaking teachers contracted to teach in Welsh speaking areas. The report was published in 1847 as Reports of the Commissioners of Enquiry into the State of Education in Wales, this was presented in three volumes bound up in blue covers and became known as the Blue Books. Amongst other opinionated statements, the report found that:

The Welsh language is a vast drawback to Wales, and a manifold barrier to the moral progress and commercial prosperity of the people. It is not easy to over-estimate its evil effects. [...] It dissevers the people from intercourse which would greatly advance their civilization and bars the access of improving knowledge to their minds. As a proof of this, there is no Welsh literature worthy of the name." (LINGEN, SYMONS AND JOHNSON, 1847, p.66)

Making a parallel to a historical event, known as "The Treachery of the Long Knives", in which Celtic Briton chieftains were betrayed and massacred by Saxons, Welsh writer Robert Jones Derfel dubbed the publication and dissemination of the report "The Treachery of the Blue Books". The treachery was manifest in the readiness of Welsh clergymen and gentry in denouncing their own fellow countrymen and ancient culture, and their acceptance and willingness to put the recommendations into effect.

During Queen Victoria's reign, the British Empire was a powerful force in the world and the feeling of British - or rather English - "superiority" was great. Similar sentiments to 
those found in the Blue Books reports were expressed by the English magnate and entrepreneur Cecil Rhodes, founder of the British colony of Rhodesia, who claimed that the world would be much better when occupied by the English. In an essay entitled Confession of Faith, Rhodes declared, "I contend that we are the first race in the world, and that the more of the world we inhabit the better it is for the human race" (RHODES, 1877). Rhodes's contemporary, the literary critic and poet, Matthew Arnold, expressed similar views. In his work Celtic Literature, published in 1891, Arnold wrote "The sooner the Welsh language disappears as an instrument of the practical, political, social life of Wales, the better; the better for England, the better for Wales itself." (ARNOLD, 1891, p.23) and further "For all serious purposes in modern literature (...) the language of a Welshman is and must be English" (ARNOLD, 1891, p.23). The imperialistic policies of the British government soon became manifest through the Education Acts introduced as a recommendation of the inquiries into the state of education in Wales. From the 1870s onwards, English language medium elementary schools were established throughout the country and English language medium intermediate education was to follow in the next decade with the establishment of secondary schools following the English Grammar school model. In this model, matters of local - i.e. Welsh - interest, were not taught. Children attended classes of economy, history, geography and science through the English perspective and language, spoken by the head teachers who were brought in from England and were unable to speak Welsh. The implications of the commissioned investigations coming from England with English Victorian values, ethics and principles - were such that the population was becoming anglicized, the traditional Welsh way of life was being oppressed and eroded and the language in permanent decline. In the Victorian age great scientific advances were being made and the English language and English standards and morals were seen by a large part of the population as the way to pull Wales out of the dark ages. In his biography of Dylan Thomas, Andrew Lycett writes, “...[parents] wanted their sons educated in the language in which business was conducted, scientific progress debated and continents governed." (LYCETT, 2005, p.7). “... [C]ontinents governed" shows an extent to which English colonialism had reached. The idea that the natives of the colonized country had to be "educated" and "civilized" was the general attitude of the English colonizer in countries such as India and Kenya (formerly known as British East Africa), Wales and the Welsh population were no exception to this imperialistic arrogance.

Meanwhile, the immigration continued into the mining communities and more and more Welsh families were finding themselves with English neighbours. The idea that the English language was the language of the future and that Welsh was moribund, primitive and ignorant 
- a concept already adopted by the landed gentry of Wales - was beginning to permeate into the lower middle and working classes of the most industrialised regions. Glyn Jones observes,

The Welsh language, at the end of the nineteenth and the beginning of the twentieth century, was associated in the minds of many Welshmen with a peasant background from which they wished to dissociate themselves, rather than with a splendid and ancient literature and a proud and independent way of life. (JONES, 2001, p. 168)

The publication of the Blue Books report also helped to foster this idea amongst the population and the Welsh language was set on a course for extinction.

The Industrial Revolution which had began in the second half of the $18^{\text {th }}$ century, was showing no signs of slowing its expansion and innovation. All over Britain the rail network was reaching into the most remote areas. With a steam powered transport system, the domestic tourist industry was booming and Victorian Londoners, wishing to have the "Celtic experience" could now arrive in Wales within hours, rather than days that the journey previously took. Despite the industrialization, the increase in the foreign population and the intense urbanization, a wild, mystical part of Wales endured, where Celtic myth, legend and history were a part of life as industry, development and technology were in the densely populated regions. It was this curiosity to explore this "wild and untamed" part of Wales that led to the production of what Ned Thomas, founder of the Welsh literature English language journal Planet, describes as "Travellers' Literature" (LLOYD, 1992). The Victorian tourist, inspired by the great adventurers Burton, Speke and Livingstone - who were at that time exploring the deepest parts of the continent of Africa - could explore a mysterious, mythical land by journeying just a few hours on a steam train. The traveller felt that he could visit a foreign land without actually leaving England, as Wales by statute was considered a province. If the most inaccessible places - Snowdonia, the Brecon Beacons - could not be reached by train, then one could read about the mysterious Celts from the comfort of an arm-chair in a hotel at the seaside resorts of Llandudno or Aberystwyth. This Travellers' Literature consisted mostly of romanticized images of the Welsh, a form of Celtic renaissance, but from the English point of view, or for the English point of view, clichéd characters, mysterious landscapes and ancient castles, green hills and dark mystical forests. Stephen Knight, professor of literature at Cardiff University, who has written extensively about Welsh English language literature, describes these travellers' books as 'first contact' literature, which developed in the $19^{\text {th }}$ century in the British colonies (KNIGHT, 2004). This first contact literature, written by both colonizer and colonized, contained descriptions of the natives and their customs and traditions and would exaggerate the more scandalous or colourful aspects of the colonized society. According to Knight, these texts, 
"range from quasi-scientific to crudely stereotypical" (KNIGHT, 2004, p.3). As well as the increased tourism due to rail travel and improved roads, the publication of the poems of Ossian by Scottish poet James McPherson in the later half of the $18^{\text {th }}$ century, promoted what Davies calls "Celtomania" (DAVIES, 2007), an interest and revival of the arts and literature of the Celtic nations, Scotland, Ireland and Wales. The Ossian poems emerge at a beginning of a renaissance from within the Celtic nations themselves, further capturing English interest. In Wales several language and cultural societies were set up with the aim of preserving the disappearing language and culture. In the late 1700's Welsh poet and antiquarian Iolo Morganwg founded the modern Bardic movement and held a Gorsedd - a gathering of Bards strategically on Primrose Hill in London in 1792. Morganwg linked the Gorsedd with the Eisteddfod, a Welsh literary, arts and music festival that can be traced back to medieval times, and organized the first of many modern Eisteddfodau (plural form) in Carmarthen in Wales in 1819. The Eisteddfodau continue until today on all levels from infant school to international festival, in both Welsh and English. The National Eistedfodd, held once a year in a different location, alternating between the north and south of Wales, is held entirely in the Welsh language, and competitions are run to select a Chief Bard.

With the reawakening of Celtic interests and ancient Welsh culture, but with a saturation of English speaking immigrants and the imperialistic educational policies, the time was now ripe for an evolution of English language Welsh literary production further to the traveller's literature. The earlier publications were still for the English market, not in the least because, until the beginning of the $20^{\text {th }}$ century, there were no publishing houses in Wales and writers had to seek to have their work published in England. As an example of this, in 1828, one of the first English language Welsh novels to be published The Adventures and Vagaries of Twm Shon Cati by T.J. Llewelyn Prichard is a high-jinx adventure which recounts the exploits of the eponymous character, a fun-loving rogue who loves to cheat, trick and rob from the English and the Welsh gentry. In other words, he is a comical stereotypical Welshman, that can be laughed at and ridiculed and yet a dangerous highwayman and robber. The character Twm Shon Cati is believed to be based on Thomas Jones, born in the $16^{\text {th }}$ century who fell foul of English law and turned to robbery and trickery to survive and help his poor Welsh neighbours and friends (ASH, 1973). In this sense, in popular Welsh folklore, Twm Shon Cati became the Welsh Robin Hood. Not all the literary production was of this nature however, Welsh consciousness for Welsh values and psyche, in the English language, was beginning to find a voice. In 1880, Swansea writer Amy Dillwyn, published The Rebecca Rioter, a first person account from the point of view of Evan Williams a young working class man who becomes 
involved in the Rebecca uprisings. Though written in English, the narrative makes it clear that the characters are speaking Welsh and they are presented without stereotypical behaviour or characteristics. A Maid of Cymru (pub. 1901) by Y Dau Wynne, pseudonym for sisters Mallt and Gwenffreda Williams, is also a strongly Welsh patriotic novel which questions the English imperial policies and prioritizes Welsh values. The principal character Tangwystyl Hywel rejects her English suitor in order to commit herself to her native Welsh culture and identity, an analogy of a Wales wishing to return to its ancient values.

The population increase and the importance of the iron and coal production of Wales brought the country a new recognition as an integral and highly significant part of Great Britain. $19^{\text {th }}$ century Wales was now emerging as a hybrid culture as the vestiges of the traditional Wales were absorbed into the new settlers' way of life, with the predominant language being that of the settlers. The emerging English language literary production would allow for Welsh traditions, experience, history, social phenomena and sentiments to be expressed in the English language. The ancient literary tradition of Wales dates back to the Bards of the Celtic tribes, who had began to settle in Britain around $700 \mathrm{BCE}$, whose function was to recount heroic tales from the tribe's history, narrate centuries of family tradition, praise great leaders and scorn and satirise enemy leaders, through epic poetry and song. Later these tales were written down, in Welsh or Latin, and some of these records, in the form of ancient manuscripts, survive, carefully preserved in museums and libraries, until today. An interesting development of this ancient culture meeting with English $19^{\text {th }}$ century colonization principles is the translation by Lady Charlotte Guest of the manuscripts known as the Mabinogion, and their implementation into the school curriculum. Though not strictly Welsh literature written in the English language, but rather translations of ancient Welsh manuscripts, the Mabinogion tales were an important contribution to the Celtic Renaissance movement owing to them being authentic texts and not fake "ancient documents" such as were the Ossian poems and much of the work of Iolo Morganwg. Born into English aristocracy, Lady Guest, daughter of the Earl of Lindsay, studied languages and literature from an early age. When she was 21 years old she married a Welsh engineer and owner of an ironworks. While living as an English aristocrat in Wales, Guest took an interest in the welfare of the workers of her husband's foundry and became involved in philanthropic projects and promoting education for the poorer mining communities of south Wales. Having learned Welsh, Lady Guest began the undertaking of translating several manuscripts known as Llyfr Gwyn Rhydderch, (The White Book of Rhydderch) and Llyfr Coch Hergest (The Red Book of Hergest), both written in the $14^{\text {th }}$ century and which contain one of the oldest Arthurian tales in Welsh, Culhwch and Olwen. These together with translations of 
other ancient works, Lady Guest published between 1838 and 1849 in a collection she entitled The Mabinogion. Guest chose the title as a derivation of the word mabynnogyon which appeared once in one of the original manuscripts and is thought to be the plural of mabinogi, itself of an obscure meaning but thought to mean 'tales of youth', this itself derived from the Welsh mab, meaning 'son' and the fact that four of the tales end with the phrase "thus ends this branch of the mabinogi" (JONES, 1989). Paradoxically, many Welsh students' contact with literature in the newly established English Grammar school system, was Guest's translation of the Welsh manuscripts. Thus they were learning their ancient heritage through a foreign language, which would more than likely propagate an interest in the culture and history of Wales. However, the new generation of students, many of them perhaps born in Wales but of English parents, were unable to express their ideas and opinions about this cultural heritage through the language of that very heritage.

As would be expected, the production of Welsh literature written in the English language was largely from the industrialized regions, those being the most susceptible to foreign immigration. Consequently, as would also be expected, the subject matter and motifs of this production was that of working class hardship, industrial toil, close knit community life, coal mining and iron smelting and the injustices imposed upon the working man. Novelists Joseph Keating - himself the son of Irish immigrants - and Jack Jones, both born in the second half of the $19^{\text {th }}$ century, in the heart of the coal production region, experienced first-hand the harsh working conditions of the coal-miner when they began working in mines at the age of 12 . Keating's first novel, Son of Judith: A Tale of the Welsh Mining Valleys (pub. 1900) uses the author's own experience to describe the harsh and dangerous conditions of the coal mines, and the difficulties faced in the valley community life. Jones' most characteristic novel, Black Parade (pub. 1934) deals with the changes, over time, of the mining and iron smelting town of Merthyr Tydfil at the beginning of the $20^{\text {th }}$ century, criticizing sanitary conditions and social problems directly affecting the working class families. The novels of both writers reflect and express the hardships endured within the communities under these harsh conditions of heavy industrialization. Curiously, Keating is listed in Glyn Jones' The Dragon Has Two Tongues and Stephen Knight's Writing Wales in English, as being a Welsh writer whose production is in the English language, but he is also referenced in Liam Harte's The Literature of the Irish in Britain (HARTE, 2009). This an indication that the children of the foreign immigrants were becoming absorbed into the Welsh culture and producing what is essentially Welsh literature written in English. It is also an indication of the hybrid culture that was forming in Wales; immigrants bringing into the county their values and ethics from their homeland, values and ethics that 
would be passed on to their children, who, in their turn, would be experiencing the everyday life in the schools and working in the heavy industries alongside their Welsh neighbours, exchanging stories and ideas.

As the production of Welsh literature written in the English language gained momentum, the question of cultural and national identity arises, as we have seen in the case of Joseph Keating, born in Wales, of Irish parents. Jones defines an author of Welsh literature in the English language as, "Welsh by blood, birth and residence [...] and a writer about Wales" (JONES, 2001, p.192). "Birth and residence" applies to the first generation onwards of the foreign immigrants, such as Keating. Without wishing to go into complex questions of national identity, Jones borrows from Irish politician Conor Cruise O’Brien's definition of Irishness as not necessarily a matter of birth, blood or language but of being immersed in and affected by the Irish situation, Jones comments, "anyone can be a Welshman who chooses to be so and is prepared to take the consequences." (JONES, 2001, p.192).

Choosing to be a Welshman or woman meant an English language education with a Welsh cultural influence or input, and for the majority of the population of Wales at the time, there was no matter of choice. By the end of the $19^{\text {th }}$ century to the first decades of the $20^{\text {th }}$ the generations growing up in Wales were a product of that education. Knight goes as far as to describe author Caradoc Evans as, "A classic victim of the 1889 Education Act." (KNIGHT, 2004, p.32). From the colonizers' point of view the "Victim" would be the privileged beneficiary of an enlightened education.

The full effect of the education policies, as well as the mass immigration throughout the $19^{\text {th }}$ century, on the generations growing up unable to speak Welsh, is seen in the first decades of the $20^{\text {th }}$ century. It is in this period that the production is such that periodicals are published, dedicated solely to English language Welsh literature, such as Wales founded by Keidrych Rhys first published in 1937 and The Welsh Review in 1939. From the end of World War II onwards, Anglo-Welsh literature has enjoyed what Knight defines as a period of integration and independence in which writers, "have tended to find ways of integrating Anglicized Wales with aspects of Cymraeg Wales, especially through location, language, cultural history and myth" (KNIGHT, 2004, p.120). In other words, "Cymraeg Wales”, (Welsh Wales) being the surviving vestiges of the ancient Celtic culture, has permeated into the English speaking communities that make up the Wales of today, and this is evident in the production of the writers of these communities.

Whether victim or beneficiary, it would be difficult to determine the degree of success that the Anglo-Welsh writers would have enjoyed had there been no colonization or 
industrialization of Wales during the $19^{\text {th }}$ century. Indeed, had history taken a different direction, it is unlikely that Anglo-Welsh literature would have emerged at all and Welsh writers would be producing their work in the Welsh language, solely for the very limited Welsh market. This most certainly would have been true for one of the best-known Anglo-Welsh writers, Dylan Thomas, born in the industrial south Wales town of Swansea in 1914. Thomas' father was a great believer of the principle that the Welsh language was an impediment to the advancement of Wales as a modern nation (despite being a Welsh speaker himself). By the time Dylan was of school age the English grammar school system of education had already been well established for some decades. As well as there being no Welsh medium school option, Dylan's parents did not allow for any Welsh speaking practice opportunity in their home environment (LYCETT, 2005). Despite this, the poet was exposed to the Celtic way of life, on his visits to relatives in the countryside of west Wales where the Welsh language still held sway. Here Dylan was exposed to another side of Welsh culture that he would not find in the city of Swansea. As a child and as a teenager, Dylan's mind was being impressed upon by these two contrasting cultures; on the one hand the conservative, English speaking grammar-school life of the big city and the Thomas family home where the head of the family insisted on English being spoken; on the other, a wild, mystical part of Wales where Celtic myth, legend and history were imbedded and infused into the society. As a consequence of this, Dylan Thomas was able to transmit these notions of unique Welshness, in content as well as style, through his writing in the English language.

To conclude and sum up, in this article I have outlined the historical background that led to the development of a Welsh literature written in the English language, also known as Anglo-Welsh writing. The colonization of Wales began in the $11^{\text {th }}$ century with a strong imposed English influence through statues and acts of union which followed over the next hundreds of years However, there is no doubt that the greatest impact on Welsh culture and identity, and ultimately on the Welsh language, was the heavy industrialization processes during the $19^{\text {th }}$ century, which induced massive foreign immigration into the region. The overcrowding and harsh working conditions incited civil unrest which forced the English government to take action in the form of radical educational reforms. The consequences of the reforms and the foreign immigration are that generations of Welsh men and women, from the $19^{\text {th }}$ century onwards, have grown up with no knowledge of their own native language and that the English language has predominated over the whole of the country of Wales with the Welsh language in steady decline with little over 30 percent of the population who use Welsh as their first language. I have selected a few of the most prominent writers from the earlier production 
as examples of Welsh writers who write in the English language, however a more comprehensive and up to date list can be found at the National Library of Wales website ${ }^{2}$.

\section{REFERENCES:}

ARNOLD, Matthew. Celtic literature. Available on-line at Project Guttenberg at $<$ http://www.gutenberg.org/files/5159/5159-h/5159-h.htm> accessed on 11 July 2018.

ASH, Russel (Ed.) Folklore myths and legends of Britain. London: Reader's Digest Association Ltd, 1973.

DAVIES, John. A history of Wales. London: Penguin Books, 2007.

DILLWYN, Amy. The Rebecca rioter. Dinas Powys: Honno, 2004.

HARTE, Liam. The literature of the Irish in Britain. London: Palgrave Macmillan, 2009.

HOOKER, Jeremy. Imagining Wales: a view of modern Welsh writing in English. Cardiff: University of Wales Press, 2001.

JONES, Glyn. The Dragon has two tongues. Cardiff: University of Wales Press, 2001.

JONES, Gwyn (translator). The Mabinogion. London: Everyman's Library, 1989.

JONES, Jack. Black parade. London: Faber, 1934.

KEATINGS, Joseph. Son of Judith: a tale of the Welsh mining valleys. London: George Allen, 1900

KNIGHT, Stephen. A hundred years of fiction: writing Wales in English. Cardiff: University of Wales Press, 2004.

LLEWELYN-PRICHARD, The adventures and vagaries of Twm Shon Cati. Available on-line at Project Guttenberg at <https://www.gutenberg.org/files/40419/40419-h/40419-h.htm> accessed on 24 July, 2018.

LINGEN, Ralph; SYMONS, Jellynger; VAUGHAN-JOHNSON, H. Reports of the commissioners of enquiry into the state of education in Wales. Available on-line at The National Library of Wales at:

https://web.archive.org/web/20080108172352/http://www.llgc.org.uk/index.php?id=theblueb ooks accessed 20 July, 2018.

LLOYD, David. Welsh writing in English: an interview with Ned Thomas. Available on-line at Jstor at: <https://www.jstor.org/stable/40148361?read-

now $=1 \& \operatorname{loggedin}=$ true\&seq=1\#page_scan_tab_contents $>$ accessed on 16 July 2018.

LYCETT, Andrew. Dylan Thomas: A new life. New York: The Overlook Press, 2005.

RHODES, Cecil John. Confession of faith. Available on-line at WebArchive at: $<$ http://web.archive.org/web/20130120204220/http://husky1.stmarys.ca/ wmills/rhodes conf ession.html $>$ accessed on 11 July 2018.

SCHAMA, Simon. A history of Britain: at the edge of the world, 3000BC-AD1603. London: BBC Worldwide Ltd. 2000.

WILLIAMS, Mallt and Gwenffreda. The maid of Cymru. London: Simkin Marshal and Co. 1901.

\footnotetext{
${ }^{2}$ Accessible at: https://www.library.wales/collections/learn-more/archives/archives-of-welsh-writers-in-english/
} 